\title{
POLIIIICOS E RELLGIĨOO NO RIO GRANDE DO SUL - BRASIL
}

\author{
Ari Pedro Oro \\ Universidade Federal do Rio Grande do Sul - Brasil
}

Resumo: Este texto constitui uma tentativa de compreensão do lugar que os políticos reservam aos seus princípios éticos e religiosos em sua prática política. Mais concretamente, analisa como os deputados da Assembléia Legislativa do Estado do Rio Grande do Sul e da Câmara Municipal de Porto Alegre lidam com as suas crenças religiosas no seu cotidiano político. Este objeto enquadra-se no debate teórico sobre a secularização, questionando-a.

Palavras-chave: política, religião, Rio Grande do Sul, secularização.

Resumé: Ce texte essaie de comprendre quelle est la place reservée par les polititiens à leurs principes éthiques et religieux lors de leur action politique. Plus concretement, il analyse comment les deputés de l'Assemblée de l'Etat du Rio Grande do Sul et du Conseil Municipal de Porto Alegre rendent compte de leurs croyances religieuses dans leur quotidien politique. Cet objet est analysé dans le contexte théorique de la sécularisation, laquelle est ici mise en question.

Keywords: politics, religion, Rio Grande do Sul, secularization.

Este texto é uma tentativa de compreensão de como os membros das casas legislativas do Rio Grande do Sul (Assembléia Legislativa) e de Porto Alegre (Câmara Municipal) lidam com suas crenças e valores religiosos em sua prática política. Ou seja, trata-se de perceber qual é o espaço e o lugar que reservam aos seus princípios religiosos e éticos e em que medida eles são interpelados em suas atividades políticas.

* Este texto resulta de uma investigação apoiada pelo Conselho Nacional de Desenvolvimento Científico - CNPq. 
Este objeto se enquadra num amplo debate teórico sobre a complexa relação, confrontação e tensão existente entre religião e modernidade ${ }^{1}$, da qual resulta a "secularização". Esta última, para alguns autores, como Bryan Wilson, constitui um processo histórico irreversível - embora ocorra de forma heterogênea segundo os países, as sociedades e as culturas - que atinge a organização da sociedade moderna, sua cultura e mentalidade coletiva. O autor britânico define secularização como o "processo pelo qual o pensamento, práticas e instituições religiosas perdem seu significado para a operação do sistema social" (Wilson, 1998, p. 49). Em outras palavras, secularização vem a ser a perda estrutural da posição hegemônica da religião na sociedade. E o político, continua Wilson, constitui um dos aspectos da organização social em que a secularização se mostra irreversível, posto que nas sociedades modernas este campo não necessita mais da legitimação religiosa. Ele encontra legitimação em si mesmo.

Vários autores compartilham com B. Wilson a idéia da secularização como um processo de autonomia das várias esferas do agir social em relação à religião, a qual se circunscreve ao âmbito do privado, da subjetividade individual. Pierucci cita mais de vinte autores favoráveis a essa teoria da secularização (1997, p. 109). Por outro lado, elenca uma dezena de outros autores que se posicionam contrariamente à teoria da secularização ${ }^{2}$, ao menos entendida na acepção acima de recuo da credibilidade e da legitimação da religião na sociedade. Para esses autores, nas últimas décadas, ao invés da anunciada "morte de Deus", "fim da religião", "declínio da religião", "eclipse do sagrado", "secularização linear e irreversível",

\footnotetext{
${ }^{1}$ Modernidade constitui uma noção complexa e ambígua que, segundo Danièle Hervieu-Léger, vista em seu processo histórico de longa duração, designa três planos:

1) uma realidade técnico-econômica ("o homem não se situa mais na natureza, mas frente a ela; ele não se pensa mais como um elemento da natureza mas como seu mestre, prosseguindo, pelo seu trabalho, a obra mesma da "criação"); 2) uma construção jurídico-política ("a modernidade reside na separação que se instaura entre a esfera da vida pública e a esfera da vida privada" ), com o consequente surgimento do Estado; 3) e uma situação psicológico-cultural ("isto é, uma certa maneira para o homem de se pensar a si mesmo como individualidade e de trabalhar para conquistar sua identidade" (Hervieu-Léger, 1987, p. 200-201). Para Jean Séguy, a modernidade conhece patamares, pois não atinge igualmente toda uma sociedade, podendo se contradizer e tomar formas diversas (Séguy, 1989).

${ }^{2}$ Não é meu objetivo discorrer sobre os vários autores que se pronunciaram a favor ou contra a secularização. Antônio Flávio Pierucci publicou, neste sentido, dois excelentes textos (Pierucci, 1997, 1998).
}

Horizontes Antropológicos, Porto Alegre, ano 7, n. 15, p. 161-179, julho de 2001 
constatam-se o "retorno do sagrado", a "revanche de Deus", o "eclipse da secularização", a "crise da secularização", o "fim do paradigma da secularização", etc. Ou seja, a atual visibilidade mediática da religião, a irrupção de novos movimentos religiosos, o sucesso da literatura esotérica, são interpretados como um fortalecimento do sagrado no contexto de uma modernidade que se mostra incapaz de resolver os problemas mais profundos do ser humano e não consegue superar as suas próprias contradições e ambigüidades internas ${ }^{3}$. Nesta perspectiva, secularização é entendida como recomposição da religião, confrontada com a racionalidade. Ou, como escreve D. Hervieu-Léger, "secularização é o processo de reorganização permanente do trabalho da religião numa sociedade estruturalmente incapaz de atender as expectativas que precisa suscitar para existir como tal" (1987, p. 227).

Este debate não se trava somente em nível internacional, pois também entre nós, autores sustentam, como o faz, por exemplo, Lísias Negrão, que “... o sagrado persistiu, é inegável que a religião aí (Brasil, Terceiro Mundo) se revitalizou, paralelamente ao reencantamento primeiro-mundista" (1994, p. 134). Enquanto outros, seguindo na direção contrária, defendem "o persistente declínio da religião" (Pierucci, 1997, p. 100).

Este pano de fundo teórico pode ainda ser complementado com idéias de autores que lidam mais diretamente com a cultura e a sociedade brasileiras. Cito dois deles. Para Gilberto Velho, "o domínio do 'sobrenatural' aparece como fundamental para compreender o sistema de representações da sociedade brasileira ou do sistema cultural propriamente dito" (1991, p. 31). Por seu turno, segundo Renato Janine Ribeiro, "O Brasil é muito marcado por um imaginário religioso...” (2000, p. 77).

Estes pressupostos teóricos estiveram na base da investigação que levamos a cabo, no ano 2000, junto a vereadores da Câmara Municipal de Porto Alegre 4 , e nos primeiros meses de 2001, junto a deputados da Assem-

\footnotetext{
3 Para D. Hervieu-Léger, a modernidade carrega em si um paradoxo pois ela "abole a religião enquanto sistema de significações e motor dos esforços humanos, mas cria, ao mesmo tempo, o espaço-tempo de uma utopia que, em sua própria estrutura, mantém afinidade com uma problemática religiosa de realização e de salvação" (Hervieu-Léger, 1987, p. 224).

${ }^{4}$ Porto Alegre é a capital do estado do Rio Grande do Sul. De acordo com o recenseamento efetuado no ano 2000 pelo Instituto Brasileiro de Geografia e Estatística (IBGE), a população dessa cidade era de 1.359.932 habitantes.
}

Horizontes Antropológicos, Porto Alegre, ano 7, n. 15, p. 161-179, julho de 2001 
bléia Legislativa do Estado do Rio Grande do $\mathrm{Sul}^{5}$. Os mesmos instrumentos de pesquisa foram aplicados em ambas as instituições e consistiram numa abordagem ao mesmo tempo quantitativa e qualitativa, a saber: um questionário composto de seis questões que solicitavam ao respondente um posicionamento justificado diante das indagações nele contidas, e um roteiro semi-estruturado de entrevistas ${ }^{6}$.

Do total de 33 vereadores que compõem o universo da Câmara $\mathrm{Mu}$ nicipal de Porto Alegre $^{7}, 28$ responderam ao questionário, ou seja, 85\% do total. As entrevistas foram realizadas com 3 deles. Já na Assembléia Legislativa, 44\% dos deputados responderam ao questionário, ou seja, 24 entre os 55 que compõem a totalidade do parlamento ${ }^{8}$. Tal como na Câmara, também 4 deputados foram entrevistados.

\section{Os informantes legislativos}

A distribuição dos políticos que colaboraram na pesquisa, segundo algumas variáveis, é a seguinte: na Câmara, no tocante ao gênero, 25 são homens e 5 são mulheres. No ano 2000, a composição da Câmara Municipal de Porto Alegre era de 27 homens e 6 mulheres. Na Assembléia Legislativa do Estado do Rio Grande do Sul, 22 são homens e 2 são mulheres. Em seu conjunto, a Assembléia Legislativa é constituída por 49 homens e 6 mulheres.

5 O Rio Grande do Sul é o estado mais meridional do Brasil e faz fronteira com a Argentina e o Uruguai. No ano 2000, segundo o recenseamento do Instituto Brasileiro de Geografia e Estatística (IBGE), a população desse estado era de 10.179.801 habitantes. Para a realização da pesquisa de campo junto a estas instituições contei com a inestimável colaboração do bolsista de iniciação científica Marcio Santos, aluno do curso de Ciências Sociais da Universidade Federal do Rio Grande do Sul.

${ }^{6}$ Obviamente que a abordagem quantitativa não tinha em vista apresentar dados "cientificamente corretos", mas tão somente indicar tendências que foram aprofundadas com recursos qualitativos de investigação antropológica.

${ }^{7}$ Em 2000, a distribuição dos vereadores segundo as siglas partidárias era a seguinte: PT (12), PTB (6), PDT (3), PPB (3), PSDB (2), PMDB (2), PFL (2), PSB (2) e PPS (1).

Em 2001, após as eleições ocorridas em outubro de 2000, as bancadas partidárias na Câmara Municipal de Porto Alegre ficaram assim constituídas: PT (10), PTB (3), PDT (5), PPB (4), PSDB (2), PMDB (3), PFL (3), PSB (1), PL (1) e PC do B (1).

${ }^{8}$ Por ocasião da pesquisa, as bancadas partidárias da Assembléia Legislativa gaúcha eram assim compostas: PT, 11 deputados, PTB (10), PDT (7), PPB (11), PSDB (2), PMDB (10), PFL (2), PCB (1) e PPS (1).

Sou imensamente grato aos vereadores e deputados que, malgrado suas múltiplas atividades, se dispuseram a colaborar com esta investigação.

Horizontes Antropológicos, Porto Alegre, ano 7, n. 15, p. 161-179, julho de 2001 
Segundo critérios de escolaridade, na Câmara 57\% dos vereadores, ou seja, 16 dos 25, possui curso superior completo. Incluindo-se os pós-graduados ( 2 com mestrado e 2 com doutorado) a porcentagem sobe para $71 \%$ do total, atingindo $81 \%$, se considerarmos também os 3 que não concluíram o curso superior. A amostra se completa com 3 que possuem o segundo grau completo, 1 o segundo grau incompleto e 1 o primeiro grau completo. $\mathrm{Na}$ Assembléia, não consta ninguém com o primeiro ou o segundo graus incompletos. Há 3 deputados com o segundo grau completo, 2 com o curso superior incompleto, 18 com o curso superior completo e 1 com mestrado. Como se vê, a porcentagem dos deputados com curso superior é de $78 \%$, alcançando $87 \%$ se somarmos aqueles que possuem curso superior incompleto. Portanto, em ambas as casas legislativas o índice dos parlamentares com curso superior excede a $80 \%$.

De uma maneira geral, tanto os vereadores quanto os deputados encontram-se distribuídos nos principais partidos políticos. Na Câmara é a seguinte a composição parlamentar dos 28 vereadores constantes desta investigação: PT (10 vereadores), PMDB (2), PSDB (2), PFL (1), PTB (6),

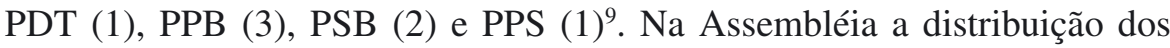
24 deputados pelos partidos é a seguinte: PPB (8), PT (5), PMDB (3), PTB (3), PDT (3), PSDB (1) e 1 sem resposta ${ }^{10}$.

Relativamente às atividades ocupacionais, os vereadores pesquisados provém de distintas profissões, sobretudo de ocupações ditas liberais (médicos, advogados, dentistas, engenheiros), em número de 9, do funcionalismo público (6), magistério (5) e jornalismo (3). Digno de nota é o fato de que 5 deles declararam a vereança como sendo a sua profissão. Por sua vez, os deputados também provém de profissões liberais (9), jornalistas (4), magistério (2), funcionários públicos (2), outras ocupações (2, 1 deles sendo sacerdote católico). Tal como ocorre com 5 vereadores, também nesta casa legislativa 5 deputados expressaram ser a atividade parlamentar a sua profissão. Este caso sugere que se trata de políticos que além de viverem "para a política", vivem também "da política", segundo a clássica proposta de M. Weber (1972).

\footnotetext{
${ }^{9}$ Comparando estes números com aqueles constantes na nota 7 , vê-se que, em relação às bancadas existentes na Câmara no ano 2000, estão ausentes nesta investigação 2 vereadores do PT, 1 do PFL e 2 do PDT.

${ }^{10}$ Nota-se, pois, que não participaram desta investigação, 3 deputados do PPB, 6 do PT, 7 do PMDB, 7 do PTB, 4 do PDT, 1 do PSDB, 1 do PCB e 2 do PFL.
} 
No que tange à religião, a maioria dos parlamentares se disseram católicos (16 entre os 28 vereadores, ou seja, 57\%, e 20 entre os 24 deputados, isto é $83 \%$ deles). Na Câmara havia 2 evangélicos e 3 na Assembléia $^{11}$. Na Câmara há 1 espírita e 9 entre os 28 , ou seja $32 \%$, que se afirmam sem religião. Na Assembléia ninguém se diz espírita e 1 diz não possuir religião.

A partir desses dados pode-se compor o perfil predominante dos políticos presentes na Assembléia Legislativa do Estado do Rio Grande do Sul e na Câmara Municipal de Porto Alegre. Trata-se de homens (embora haja cerca de $11 \%$ de mulheres na Assembléia e de $20 \%$ na Câmara Municipal $)^{12}$, que possuem o curso superior, completo ou incompleto (embora haja cerca de $20 \%$ com o segundo grau, e alguns raros com o primeiro grau), que se afirmam como católicos (embora haja também membros de outras expressões religiosas como a evangélica e mesmo a espírita, este último na Câmara Municipal, além de um grupo de cerca de 5\% na Assembléia e 30\% na Câmara que se dizem sem religião), provenientes de distintas atividades profissionais, com destaque para funções liberais, funcionalismo público, magistério e jornalismo ${ }^{13}$.

\footnotetext{
${ }^{11}$ Neste ano de 2001, na Câmara Municipal, após as eleições de outubro de 2000, houve alguma alteração no perfil dos vereadores que estamos apresentando. No entanto, persiste ali 2 vereadores evangélicos, agora ambos da Igreja Universal do Reino de Deus. Antes, 1 era da Assembléia de Deus e outro não parece ter vínculo exclusivo com uma denominação evangélica. Na Assembléia, na legislatura em curso há 4 deputados evangélicos e 1 sacerdote católico.

${ }^{12}$ Celi Regina Pinto coordenou uma pesquisa realizada junto às vereadoras eleitas no Rio Grande do Sul nas legislaturas 1992 e 1996, e levantou o seguinte perfil das mesmas: a sua maioria possui mais de 40 anos, são casadas e tem apenas dois filhos, possuem alto grau de escolaridade (um número expressivo possui o terceiro grau), e trabalham no setor de serviços, magistério e profissões liberais.

Relativamente às trajetórias dessas vereadoras a mencionada pesquisa mostrou, também, que a maioria delas pretendem se manter na arena política, e "no que pese sua entrada tardia como detentoras de cargo eletivo, tiveram uma significativa inserção na vida política e comunitária de suas cidades, militando em partidos e em movimentos sociais e exercendo, principalmente nesses últimos, papel de liderança" (Pinto et al., 2000, p. 44).

No tocante ao desempenho das vereadoras do Rio Grande do Sul, a pesquisa revelou que "quando há uma identificação com grupos específicos nos projetos que pretendem apresentar, essa identificação é com a mulher". Isto significa que um número significativo de mulheres que chegam à vida política "tem bastante claras as questões de gênero, as questões de discriminação e usam seu mandato para propagar os direitos da mulher" (Pinto et al., 2000, p. 64-65).

${ }^{13}$ Como se vê, pode-se aplicar para esta região do Brasil a frase de Weber, segundo o qual a carreira jornalística constitui “... uma das vias mais importantes de atividade política profissional" (Weber, 1972, p. 83).
}

Horizontes Antropológicos, Porto Alegre, ano 7, n. 15, p. 161-179, julho de 2001 
Pode-se inferir, pois, que os membros das duas casas legislativas provém das classes médias e das classes positivamente privilegiadas, segundo a terminologia de Max Weber.

\section{A religião e a imagem do político}

Indagados se no Rio Grande do Sul a imagem pessoal de um político pode ser afetada, inclusive no sentido de prejudicar a sua votação, caso expresse publicamente a sua condição de ateu ou de sem religião, 18 vereadores se pronunciaram positivamente, ou seja, $64 \%$ do total investigado, enquanto que 8 vereadores, isto é, $28 \%$ deles, se posicionaram contrários à relação acima e 2 afirmaram não possuir uma opinião formada acerca da questão. Na Assembléia Legislativa a porcentagem dos que responderam positivamente é ainda maior. Com efeito, 79\% deles, isto é, 19 entre 24 deputados, consideram que a imagem de um político está socialmente comprometida caso se afirme sem vínculo religioso. Foram 3 os deputados que responderam negativamente, 1 optou pelo sim e pelo não e 1 não tomou nenhuma posição diante da questão.

Isto significa que para a maioria dos vereadores da Câmara Municipal de Porto Alegre e dos deputados da Assembléia Legislativa gaúcha, os políticos que veiculam publicamente seu vínculo religioso tendem a recolher uma aceitação social favorável, enquanto que tendem a prejudicar a sua imagem os políticos que expressam uma condição não religiosa.

As alegações tanto dos vereadores quanto dos deputados que responderam positivamente à questão acima centralizam-se no reconhecimento do forte peso que a religião, sobretudo o catolicismo, detém na formação histórica do Rio Grande do Sul e do Brasil, que chegou a moldar culturalmente as identidades regional e nacional. Desta forma, ponderam: o homem público precisa acompanhar e sintonizar-se com este perfil cultural. Somente assim obterá a confiança do povo. Caso contrário, perde a simpatia de parte significativa do eleitorado.

Eis algumas frases, neste sentido, ditas pelos vereadores:

- "A religião, a fé em Deus faz parte do povo gaúcho";

- "O nosso povo é religioso";

- "O sentimento religioso é forte na maior parte da nossa população"; 
- "O povo não tem confiança em quem não é religioso".

- "O político manifestamente ateu se antagonizará com o povo, ao contrariar-lhe as convicções";

- "Dizer-se ateu ainda causa impacto";

- "Para um político, revelar seu ateísmo prejudica a imagem e tem como conseqüência a perda de votos".

Por sua vez, alguns deputados assim se expressaram sobre a questão:

- "Somos um estado, em função das suas etnias, extremamente religioso. O político que não acompanhar a cultura e os costumes da população certamente terá prejuízos";

- "A grande maioria da população é religiosa";

- "Existe uma imagem extremamente depreciativa, com base em preconceitos, associada ao indivíduo ateu";

- "Vivemos em um estado onde o sentimento religioso é muito presente no povo e alguém que se apresente como ateu perde a simpatia de muitos";

- "A religião está bastante enraizada na cultura da população".

Os 8 vereadores que responderam negativamente à relação entre expressão pública da religião por parte dos atores políticos e sua imagem social favorável, argumentam que vivemos numa sociedade democrática, onde ninguém pode ser discriminado por razões religiosas, que sabe separar a religião dos demais campos sociais, além de sublinharem que o mais importante nos políticos é sua honestidade e transparência, independentemente de ser ou não religioso.

Eis algumas frases ditas por esses vereadores:

- "Vivemos numa sociedade democrática [...] e ninguém pode ser discriminado em razão de sexo, religião, cor, etc";

- "A consciência política dos gaúchos já superou este primarismo [associar religião e política]";

- "A religiosidade, esporte e política estão em campos separados";

Por seu turno, os 3 deputados que responderam negativamente a essa questão justificam que a expressão identitária religiosa do político não 
detém, em nossa sociedade, um peso tão determinante e que a captura de votos está relacionada a outras variáveis. Eis, neste sentido, duas frases textuais:

- "Acredito que há um crescente voto congregacional, mas o fato ateu não teria interferência porque há outros critérios: regional, de categoria, partidário, outro valor ético, estrutura financeira, empresas...";

- "Existem outras razões de voto mais relevantes [do que a afirmação religiosa]".

Os 2 vereadores que não tomaram uma posição, na verdade detém uma opinião comum ao ponderarem que o Rio Grande do Sul não é homogêneo, havendo uma importante diferença de mentalidade entre os moradores das grandes e das pequenas cidades, ou seja, entre os habitantes das zonas urbanas e interioranas. Nas primeiras, diz um deles, "é mais elevado o nível de informação e de aceitação da diferença no campo das idéias e das opções individuais". Neste caso, "o prejuízo (eleitoral) é mínimo" (para o político que se diz publicamente ateu). No entanto, continua o mesmo informante, "no interior, onde o pensamento é mais conservador, portanto mais intolerante e arredio ao novo, o prejuízo é arrasador". Semelhante posição foi assumida por um deputado que considera o tema da religião mais importante nas regiões rurais do que urbanas.

\section{A religião no quotidiano dos políticos}

Indagados se a moral religiosa, as crenças e os valores pessoais, devem ser trazidos para a prática política, mesmo nos momentos de votação, as respostas foram afirmativas para 16 vereadores, isto é, 57\% deles, e negativas para 12, ou seja, $43 \%$ dentre eles. Entre os deputados, as respostas positivas foram em número bastante maior: $75 \%$ dos questionados, ou seja, 18 deputados, enquanto que 5, isto é, 20\% deles, responderam negativamente e 1 optou por uma resposta ao mesmo tempo positiva e negativa.

Pode-se dizer, mesmo que metaforicamente que, para a maioria dos políticos gaúchos que participaram da pesquisa, tal como afirmou Max Weber, "a política se faz com o cérebro, mas indiscutível, também, que ela 
não se faz exclusivamente com o cérebro" (1972, p. 121). Em outras palavras, princípios éticos, religiosos, paixão, também compõem o fazer político, além da racionalidade e da burocracia.

Os 16 vereadores e os 12 deputados que se manifestaram no sentido de afirmar a aproximação entre os componentes éticos, axiológicos e religiosos do seu universo de representação simbólica e sua prática política, direta ou indiretamente, sustentam que a moral e os princípios religiosos devem orientar e nortear a vida das pessoas, também dos políticos.

Eis algumas frases que vão neste sentido, ditas pelos vereadores:

- "Os princípios religiosos são importantes nas decisões e contribuem para que a política seja perpassada pela ética, moral e sentimento humanista";

- "A questão religiosa sempre dá orientação. Os valores cristãos são prioritários";

- "Sempre preservei os valores humanistas do cristianismo. São referências para mim";

- "Os valores e crenças políticas que trago da minha formação cristã certamente influenciam meus atos [...] com outras vivências e experiências são balizadoras da minha ação política";

- "A moral deve orientar a vida das pessoas onde quer que estejam";

- "A moral religiosa é a que tem melhor acabamento socio-psicológico";

- "A moral religiosa, se o indivíduo a formar, faz com que ele seja sério, responsável, preocupado com seu semelhante";

- "A moral está sempre presente na política".

Seguem, na mesma linha, algumas frases pronunciadas pelos deputados:

- "Minha atuação política não está dissociada de minha prática religiosa";

- "Valores como a ética e a solidariedade devem nortear nossas decisões";

- "Sempre voto consultando a minha consciência, a constituição e as leis. Nesta ordem. A consciência está vinculada, evidentemente, à religião"; 
- "A moral religiosa se aproxima, ao fim, da ética política";

- "O homem sem religião, sem fé, não é nada";

- "Não se pode fazer política sem ética";

- "Uma moral religiosa reforça os valores fundamentais que devem estar presentes no exercício da política, tais como o humanismo, a fraternidade, o respeito ao próximo, a honestidade no trato com o dinheiro público";

- "Não há uma moral religiosa separada do ser humano ou que "fique em casa", enquanto ele vai exercer sua profissão. Toda a ação do político vai demonstrar suas crenças".

As respostas negativas à presença da moral e das crenças religiosas dos políticos em sua prática política são justificadas, por 12 vereadores da Câmara Municipal de Porto Alegre e por 5 deputados da Assembléia Legislativa do Estado, a partir de argumentos tais como: o político precisa ser livre para pensar e agir, não amarrado e dependente de pressupostos religiosos; o político precisa pautar sua conduta pela sua consciência e responsabilidade e não pela sua religião; por serem representantes de uma sociedade plural, na qual estão incluídos ateus, agnósticos e detentores de diferentes crenças e moralidades, precisam colocar entre-parenteses suas convicções pessoais; enfim, deve-se separar a política (que é uma questão pública e racional) da religião (que concerne o espaço da intimidade e da subjetividade).

Eis algumas frases ditas textualmente pelos vereadores:

- "Os políticos representam uma parte da sociedade que podem ser os ateus, agnósticos, etc. A pluralidade da sociedade tem que ser respeitada";

- "Um comportamento ético ou moral não é privilégio das religiões";

- "Deve-se separar a visão do Estado [que é política] da visão da religião [que é espiritual e íntima de cada um]";

- "Não sou religioso e ninguém colocou à tona ou condicionou o meu mandato em razão de não ser religioso";

- "Religião, fé, crença, são coisas muito pessoais. Não as misturo com política"; 
- "O político deve ser orientado em sua conduta por sua consciência e pela responsabilidade que deve ter por seus atos e escolhas e não pela sua religião";

- "Porque sempre atuo com a razão e penso em todos igualmente, independentemente de religião".

Ouçamos agora algumas frases ditas pelos deputados:

- "A moral religiosa é uma opção individual, muitas vezes descontextualizada historica e politicamente. Nenhum tipo de dogmatismo contribui, no meu entender, com a ação política";

- "Não podemos transformar em lei para todos questões e opções que são de fórum íntimo".

\section{As fronteiras entre religião e política}

Uma indagação mais direta no sentido de ouvir dos legisladores se política e religião devem compor campos separados ou relacionados, obteve, junto aos vereadores, um percentual de $78 \%$, ou seja, 22 deles, que se posicionaram pela separação dos campos, enquanto que $18 \%$, isto é, 5 deles, se manifestaram pela sua aproximação; 1 não tomou nenhuma posição. Entre os deputados o número dos que consideram religião e política enquanto campos separados é menor. Mesmo assim, trata-se de $50 \%$ deles, ou seja, 12 deputados, enquanto que 37\%, isto é, 9 deputados, consideram imbricados os campos, 1 respondeu ao mesmo tempo positiva e negativamente e 2 não tomaram posição.

Os vereadores e deputados que propõem fronteiras entre o político e o religioso recorrem aos argumentos de que tal separação resulta de uma conquista do positivismo e da moderna democracia, que tem conduzido à laicização, à democracia política (cujo resultado é uma postura política que deve estar acima dos faccionalismos ou preferências religiosas), e à separação dos campos, cabendo ao político as questões de ordem pública, e à religião as situações espirituais da esfera subjetiva. Alem disso, outros políticos ponderam que a aproximação entre religião e política pode conduzir a fundamentalismos e totalitarismos. 
As frases abaixo explicitam as colocações acima:

- "A separação [religião e política] é uma das conquistas do Positivismo";

- "A separação [religião e política] é para manter a laicidade da política";

- "Numa democracia impõe-se a liberdade religiosa, com toda sua pluralidade; necessariamente o político democrata tem que atuar desvinculando a política do religioso, com respeito a todos os cidadãos";

- "A religião é uma coisa íntima, subjetiva, muito pessoal de cada um";

- "A política é uma questão ideológica [...]. A religião é de foro íntimo";

- "A política trata do lado material e a religião do espiritual";

- "Não devemos utilizar desta convicção (religiosa), que é privativa

e pessoal, para alicerçar os projetos políticos";

- "A mistura da política com a religião conduz à intolerância religiosa que é uma forma de totalitarismo e autoritarismo que a humanidade já experimentou".

Por seu turno, alguns deputados assim se pronunciam acerca da separação entre religião e política:

- "A política deve tratar sobre as grandes questões que buscam o bem para a humanidade como um todo, independente da opção religiosa do parlamentar";

- "Política não se funde nem confunde com religião";

- "Religião e política são esferas distintas da realidade";

- "Seria melhor não misturar. Mas é muito difícil esta separação".

Mas, contrariamente às posições acima, 5 vereadores e 9 deputados tendem a juntar e não separar religião e política. E mais, alegam que o religioso constitui a instância fundamental sobre a qual se assentam os demais campos da vida social. Em outras palavras, para eles a religião é tida como um elemento encompassador da vida humana, também política. 
Eis algumas frases ditas pelos vereadores:

- "O religioso deve ser a base de tudo, inclusive apoiando a política";

- "A religião faz parte da vida humana, integra todo o seu ser";

- "Acaso alguém pensa desvincular da política a filosofia, a economia, a sociologia, a informática ou o marketing?”.

Seguem algumas frases ditas pelos deputados:

- "Tudo tem vinculação, de uma forma ou de outra";

- "Não se pode fazer política sem espiritualidade";

- "Nada está dissociado das decisões políticas. A própria prática religiosa é uma forma de fazer política. Talvez não a política partidária; mas, do ponto de vista ideológico, todos têm posição";

- "Os dois campos [religioso e político] têm valores comuns, o que os vincula na busca de um mesmo objetivo, que é o da construção de uma sociedade baseada nos princípios da solidariedade e da justiça social".

\section{Discussão}

Quando os políticos que colaboraram nesta investigação afirmam-se, de um lado, majoritariamente religiosos $(68 \%$ dos vereadores e $95 \%$ dos deputados) e, de outro, pronunciam-se pela separação da política do religioso (78\% dos vereadores e 50\% dos deputados), estão assumindo e aceitando a idéia de secularização em seus sentidos de laicização - ou seja, "processo pelo qual as diversas instituições sociais conquistam sua autonomia e se dotam de ideologias, de referências, de regras de funcionamento próprios" (Hervieu-Léger, 1986, p. 193) - e de privatização do sagrado, isto é, a situação em que os sentidos da religião circunscrevem-se à órbita da subjetividade e do íntimo (Pierucci, 1997; Wilson, 1998).

Assim procedendo, esses políticos tendem a reproduzir uma situação atual mais geral da sociedade ocidental, apontada por Marcel Gauchet. De fato, este antropólogo francês apresenta uma síntese do processo religioso na sociedade moderna e propõe que nos inícios da humanidade prevaleceu a religião "pura", em que o sagrado era estruturante do existir social. Em seguida, surgiu a fase da religião da transcendência, onde o princípio 
fundante do social foi posto fora do mundo visível. Ocorreu, então, a emergência da subjetividade humana, a religião passou a cumprir funções sociais, sendo o cristianismo considerado pelo autor como a religião da saída da religião. Enfim, encontramo-nos no tempo da crise da religião transcendente posto que ela não é mais instituinte e organizadora do social. Ou seja, hoje a religião restringe-se à esfera subjetiva e não possui mais eficácia social, posto que a sociedade se organiza e se reproduz sem a necessidade da religião. Vivemos, segundo Gauchet, numa "sociedade atéia composta e governada por uma maioria crente" (Gauchet, 1985) ${ }^{14}$.

No entanto, quando $57 \%$ do total dos mesmos vereadores e $70 \%$ dos deputados afirmam que interpelam os seus princípios religiosos em sua prática política, e quando $64 \%$ do total dos vereadores e $79 \%$ dos deputados revelam que a imagem pública de um político pode ser atingida caso exteriorizem posições de distanciamento do religioso, estão, em certa medida, reconhecendo a incapacidade da política, por si só, de dar plenas respostas aos problemas individuais e coletivos, sobretudo àqueles que dizem respeito aos aspectos mais fundamentais da existência humana, como o sentido da vida (Prandi, 1992). Mas, sobretudo, ao considerarem que a agenda política não pode ocorrer separada de uma moral religiosa, e que suas crenças e valores religiosos são trazidos para a prática política, ou seja, ao atribuírem algum significado à religião na operação do sistema político, ou então - para usar uma expressão de André Corten constante em texto presente neste volume - ao admitirem um imaginário político composto também de forças invisíveis, esses mesmos políticos estão se distanciando das posições de Gauchet - certamente válidas para outras sociedades e culturas do mundo ocidental, sobretudo européias - e mantendo fidelidade em relação à cultura e à sociedade brasileiras, muito marcada por um imaginário religioso, como disse Renato Janine Ribeiro, onde, retomando Gilberto Velho, "o domínio do 'sobrenatural' aparece como fundamental" (1991, p. 31), e onde observa-se uma imbricação entre o mágico e o racional (Montero, 1994).

Essas constatações realizadas nas casas legislativas gaúchas abrem um leque de observações, sugestões e questionamentos, algumas das quais serão agora brevemente apresentadas.

14 Para uma síntese desta abordagem de Gauchet ver Steil (1994). 
Em primeiro lugar, a autonomia do político em relação ao religioso parece consistir, para os membros das casas legislativas em questão, sobretudo como algo desejável, posto que na prática, direta ou indiretamente, de uma forma ou outra, a religião, enquanto dado de cultura e de subjetividade, é, por eles, trazida para a ação e prática políticas, embora, como observou B. Wilson, nas sociedades modernas o poder político não necessita mais da legitimação religiosa (1998, p. 50). Em outras palavras, ao observarmos que o quotidiano dos políticos das casas legislativas gaúchas não ocorre, em alguma medida, distanciada da moral e da religião, sugerimos que a análise poderia alcançar melhor resolução se, ao invés de uma perspectiva dualista, que opõe autonomia do político (esfera da racionalidade) em relação à religião (campo da emoção e irracionalidade) e religião legitimando o sistema político (e social), fosse privilegiado uma abordagem ideal-típica que contemplasse a existência de um gradiente entre autonomia plena do político (em relação à religião) e plena incidência religiosa (também sobre o político), cuja variabilidade estaria relacionada com as especificidades históricas e culturais de cada país ou região. Ademais, é previsível que a relação entre política e religião seja dinâmica, ora se aproximando e ora se distanciando, segundo idiossincrasias próprias das sociedades e das culturas.

Em segundo lugar, secularização é um conceito útil para se compreender nossa sociedade ${ }^{15}$, entendida menos no sentido de declínio de crença e prática religiosa em si, difícil de contabilizar, como observa B. Wilson (1998), e preferencialmente no sentido que lhe atribui D. Hervieu-Léger (1987), ou seja, enquanto transformação e recomposição do campo religioso em razão da própria mudança da sociedade ou, como propõe Pierucci, "secularização como a passagem de uma situação de monopólio ou hegemonia de uma única religião para um cenário diversificado de pluralismo religioso plenamente aceito e definitivamente instalado..." (1997, p. 116) ${ }^{16}$. É, neste sentido, significativa a presença, em ambas as casas legislativas referidas, de representantes, além do catolicismo, de outra importante expressão religiosa

\footnotetext{
15 Pierucci propõe que não se abra mão do conceito de secularização. "Nem teórica, nem prática, nem terminológica, nem existencialmente." (1998, p. 67).

16 Além disso, Pierucci sublinha que secularização precisa ser vista "como desenraizamento dos indivíduos [...]. É apenas nessa operação de arrancar de seu hábitat cultural o indivíduo que ela (secularização) se põe e se efetiva como dessacralização da cultura." (1997, p. 114).
}

Horizontes Antropológicos, Porto Alegre, ano 7, n. 15, p. 161-179, julho de 2001 
que compõe a diversidade religiosa brasileira, a evangélica, e mesmo a mediúnica, na Câmara Municipal de Porto Alegre.

Em terceiro lugar, e intimamente associado ao que precede, e seguindo a proposição de Hellemans ${ }^{17}$, parece difícil imaginar entre nós a predominância de oposições e rupturas entre religião e modernidade e religião e política. Haveria, antes, preferencialmente implicações mútuas entre elas, não sem choques e atritos evidentemente, que asseguram, em alguma medida, espaço e sentido ao simbólico na modernidade (religiosa) gaúcha (e brasileira).

Enfim, retomando o nosso objeto específico - a relação que os parlamentares locais estabelecem entre sua prática política e seus princípios éticos e religiosos - fica em aberto, entre outras, quatro questões:

a) Quando os políticos gaúchos dizem acionar em seu quotidiano político seus princípios ético-morais, valores e crenças religiosas, estão falando a mesma coisa ou o significado desses conceitos varia segundo a concepção, formação e vínculo religioso de cada parlamentar?

b) Qual seria, efetivamente, a incidência das subjetividades religiosas que os políticos gaúchos dizem levar em consideração em sua ação política na dinâmica do poder político local, do qual eles compõem uma parte significativa?

c) Esses parlamentares que se declaram majoritariamente religiosos e éticos, pautam a sua prática política a partir da "ética da convicção" ou da "ética da responsabilidade", ou da complementariedade entre ambas? ${ }^{18}$

d) Enfim, malgrado a menor representatividade dos deputados em relação aos vereadores nesta investigação, pode-se perceber que, de uma maneira geral, os primeiros, mais do que os segundos, posicionam-se preferencialmente pelo reconhecimento de relações, influências e imbricações

\footnotetext{
17 Este autor advoga não uma oposição entre religião e modernidade, que está na base da teoria da secularização, mas um entrelaçamento estreito entre ambas, a religião fazendo parte integral da modernidade (Hellemans, 1998).

18 Lembro que, segundo Weber, a ética da convicção consiste numa ética orientada para os fins, enquanto que a ética de responsabilidade consiste numa ética orientada para os meios. Porém, continua o sociólogo de Heidelberg, "isso não quer dizer que a ética da convicção equivalha a ausência de responsabilidade e a ética da responsabilidade, a ausência de convicção" (Weber, 1972, p. 113). Igualmente, para Weber, “[...] a ética da convicção e a ética da responsabilidade não se contrapõem, mas se completam e, em conjunto, formam o homem autêntico, isto é, um homem que pode aspirar à "vocação política” (1972, p. 122).
}

Horizontes Antropológicos, Porto Alegre, ano 7, n. 15, p. 161-179, julho de 2001 
mútuas, tanto em nível pessoal, ou seja, deles próprios, quanto coletivo, entre religião (ética, crenças) e política. Ora, essa declarada presença da ética, ou preocupação pela mesma, constante no discurso dos parlamentares gaúchos, deve-se a um componente estrutural da cultura política riograndense ou consiste numa reação em favor da moralização da política diante do momento atual da política brasileira, em que assistimos repetidas denúncias de desvio de verbas públicas, propinas, "escândalos" de corrupção, ou seja, de aviltamento à ética que estão irrompendo em distintos níveis da vida política nacional?

\section{Referências}

DA MATTA, Roberto. In: COUTO, J. G. (Org.). Quatro autores em busca do Brasil. Rio de Janeiro: Rocco, 2000. p. 89-107.

GAUCHET, Marcel. Le Désenchantement du Monde: une histoire politique de la religion. Paris: Gallimard, 1985.

HELLEMANS, Staf. Secularization in a religiogeneous modernity. In: LAERMANS, Rudy; WILSON, Bryan; BILLIET, Jaak. Secularization and Social Integration: Papers in Honor of Karel Dobbelaere. Leuven: Leuven University Press, 1998. p. 67-81.

HERVIEU-LÉGER, Danièle. Vers un nouveau Christianisme? Paris: Cerf, 1987.

MONTERO, Paula. Magia, racionalidade e sujeitos políticos. Revista Brasileira de Ciências Sociais, n. 26, p. 72-90, out. 1994.

NEGRÃO, Lísias Nogueira. Intervenção. In: MOREIRA, Alberto; ZICMAN, R. (Org.). Misticismo e novas religiões. Petrópolis: Vozes, USF/FAN, 1994. p. 130-135.

PIERUCCI, Antônio Flávio. Reencantamento e dessecularização: a propósito do auto-engano em sociologia da religião. Novos Estudos do Cebrap, n. 49, p. 99-117, nov. 1997.

- Secularização em Max Weber: da contemporânea serventia de voltarmos a acessar aquele velho sentido. Revista Brasileira de Ciências Sociais, v. 13, n. 37, p. 43-73, jun. 1998. 
PINTO, Céli Regina et al. Perfis, trajetórias, desempenhos: uma pesquisa com as vereadoras gaúchas. Porto Alegre: Editora da UFRGS, 2000. PRANDI, Reginaldo. Perto da magia, longe da política: derivação do encantamento no mundo desencantado. Novos Estudos do Cebrap, São Paulo, n. 34, p. 81-91, 1992.

RIBEIRO, Renato Janine. In: Couto, J. G. (Org.). Quatro autores em busca do Brasil. Rio de Janeiro, Rocco, 2000. p. 57-87.

SÉGUY, Jean. Modernité religieuse, religion métaphorique et rationalité. Archives des Sciences Sociales des Religions, Paris, n. 67/2, p. 191-210, 1989.

STEIL, Carlos Alberto. Para ler Gauchet. Religião e Sociedade, n. 16/3, p. 24-49, maio 1994.

VELHO, Gilberto. Indivíduo e religião na cultura brasileira. Sistemas cognitivos e sistemas de crença. Novos Estudos Cebrap, São Paulo, n. 31, p. 121-129, out. 1991.

WEBER, Max. Ciência e política: duas vocações. 2. ed. São Paulo: Cultrix, 1972.

WILSON, Bryan. The secularization thesis: Criticisms and rebuttals. In: LAERMANS, Rudy; WILSON, Bryan; BILLIET, Jaak. Secularization and Social Integration: Papers in Honor of Karel Dobbelaere. Leuven. Leuven University Press, 1998. p. 45-65. 